\title{
Pengaruh Persentase Serbuk Ampas Tebu terhadap Sifat Fisik dan Mekanik Papan Semen Partikel
}

\author{
Wenni Fitri*, Mora \\ Laboratorium Fisika Material, Jurusan Fisika \\ Fakultas Matematika dan Ilmu Pengetahuan Alam, Universitas Andalas \\ Kampus Unand, Limau Manis, Padang, 25163 \\ *fitriwenni@gmail.com
}

\begin{abstract}
ABSTRAK
Telah dilakukan penelitian mengenai pengaruh persentase serbuk ampas tebu terhadap sifat fisik dan mekanik papan semen partikel. Uji sifat fisik meliputi uji densitas, daya serap air dan porositas, sedangkan uji sifat mekanik terdiri dari uji kuat tekan dan kuat lentur dengan perawatan papan selama 28 hari. Persentase serbuk ampas tebu yang digunakan adalah $0 \% ; 2,5 \% ; 5 \% ; 7,5 \%$ dan $10 \%$ terhadap volume cetakan dengan ukuran 100 mesh. Hasil uji sifat fisik menunjukkan bahwa densitas terendah dicapai papan semen partikel sebesar $1,696 \mathrm{~g} / \mathrm{cm}^{3}$ dengan penambahan $10 \%$ serbuk ampas tebu, daya serap air rata-rata tertinggi pada papan semen partikel sebesar $12,77 \%$ dengan persentase serbuk ampas tebu $10 \%$, porositas rata-rata tertinggi pada papan semen partikel sebesar $21,67 \%$ dengan persentase serbuk ampas tebu $10 \%$. Hasil penelitian untuk uji sifat mekanik menunjukkan bahwa kuat tekan rata rata tertinggi adalah $52,4 \mathrm{~kg} / \mathrm{cm}^{2}$ dengan penambahan serbuk ampas tebu $5 \%$ dan kuat lentur rata - rata tertinggi pada papan semen partikel adalah $40,5 \mathrm{~kg} / \mathrm{cm}^{2}$ dengan penambahan serbuk ampas tebu $0 \%$. Penambahan 5\% serbuk ampas tebu merupakan persentase optimum pada uji kuat tekan yang dapat ditambahkan pada papan semen partikel. Nilai densitas dan daya serap air telah memenuhi SNI 03-21052006, namun untuk uji sifat mekaniknya belum memenuhi SNI 03-2105-2006.

Kata kunci: densitas, daya serap air, porositas, serbuk ampas tebu, kuat lentur, kuat tekan, papan semen.
\end{abstract}

\begin{abstract}
A research on effect of bagasse powder percentage on the physical and mechanical properties of cement particle boards has been conducted. Physical properties test included density, water absorption and porosity, while the mechanical properties test consisted of compressive strength and flexural strength with 28 days of board maintenance. The percentage of bagasse powder used is 0\%; $2.5 \%$; $5 \%$; $7.5 \%$ and $10 \%$ of the volume of prints with 100 mesh size. The results showed that the lowest density was achieved by cement particle board with the addition of $10 \%$ bagasse powder that is $1.696 \mathrm{~g} / \mathrm{cm}^{3}$, the highest water absorption capacity is $12.77 \%$ with a percentage of $10 \%$ powder, the highest average porosity is $21.67 \%$ with $10 \%$ bagasse powder percentage. The results of the research to test the mechanical properties showed that the highest average compressive strength is $52.4 \mathrm{~kg} / \mathrm{cm}^{2}$ with the addition of $5 \%$ powder and the highest flexural strength is $40.5 \mathrm{~kg} / \mathrm{cm}^{2}$ with the addition of $0 \%$ bagasse powder. The addition of 5\% bagasse powder is the optimum percentage in the compressive strength test that can be added to the cement board. Density and water absorption values has met SNI 03-2105-2006 standard, but for mechanical properties has not fulfilled SNI 03-2105-2006 standard.

Keywords: density, water absorption, porosity, bagasse powder, flexural strength, compressive strength, cement board.
\end{abstract}

\section{PENDAHULUAN}

Indonesia merupakan salah satu negara berkembang yang banyak melakukan pembangunan di berbagai sektor, salah satunya pembangunan di sektor perumahan. Hal ini mengakibatkan permintaan terhadap bahan bangunan meningkat. Salah satu material yang digunakan sebagai bahan bangunan adalah material komposit. Material komposit banyak digunakan karena adanya keuntungan dalam penggunaannya seperti konstruksi menjadi ringan, mudah dibentuk, tahan terhadap korosi dan proses pembuatan yang mudah. Salah satu cara mengatasi permintaan material komposit yang semakin meningkat adalah pembuatan papan semen partikel (Nopriantina., 2013).

Menurut Sutigno., dkk (1977) papan semen partikel adalah salah satu produk komposit kayu yang terbuat dari partikel-partikel kayu atau bahan berlignoselulosa lainnya dan semen sebagai perekatnya. Papan semen memiliki kelebihan antara lain adalah tahan terhadap jamur, serangga, api, kelembaban serta mudah dibentuk. Papan semen tersusun dari material yang mengkombinasikan matriks dengan filler. Matriks berfungsi sebagai bahan pengikat sedangkan 
filler merupakan pengisi komposit. Secara umum, filler digunakan untuk meningkatkan kekerasan, kekuatan, ketangguhan, stabilitas, modulus elastisitas serta konduktivitas panas dan listrik. Pada penelitian ini filler yang digunakan yaitu ampas tebu dengan ukuran 100 mesh, serta mengunakan semen sebagai matriksnya .

Penelitian tentang ampas tebu telah dilakukan sebelumnya oleh Iswanto (2009) dengan melihat pengaruh perendaman partikel terhadap sifat fisis dan mekanis papan partikel dari ampas tebu. Penelitiannya menunjukan bahwa papan partikel terbaik dihasilkan pada perlakuan perendaman partikel dalam air panas selama 2 jam. Hasil pengujian papan partikel telah memenuhi standar JIS (Japanese Industrial Standard) A 5908-2003 dan Standar Nasional Indonesi (SNI) 032105-1996, kecuali untuk nilai modulus elastisitas rata-rata $8.228,5 \mathrm{~kg} / \mathrm{cm}^{2}$ masih di bawah standar yang dipersyaratkan.

Pardede (2014) melakukan penelitian dengan judul analisa kajian tegangan beton dengan campuran serat ampas tebu (bagasse). Komposisi ampas tebu yang digunakan dimulai dari $15 \%$ sampai $40 \%$. Dari penelitian yang telah dilakukan didapatkan hasil bahwa nilai daya serap air meningkat seiring dengan penambahan serat ampas tebu, sedangkan untuk pengujian kuat tekan hasil terbaik didapatkan sebesar $178,037 \mathrm{~kg} / \mathrm{cm}^{2}$ pada persentase ampas tebu $15 \%$. Peneliti menyarankan untuk penelitian selanjutnya digunakan ampas tebu di bawah $15 \%$.

Ampas tebu merupakan limbah padat yang berasal dari proses pemerasan batang tebu. Ampas tebu mengandung air $48-52 \%$, gula 2,5 - 6\%. Selama ini limbah dari ampas tebu dimanfaatkan sebagai bahan bakar, padahal limbah dari produksi gula tebu sangat berpotensi untuk dimanfaatkan dalam kegiatan kontruksi. Ampas tebu tidak larut dalam air dan sebagian besar terdiri dari selulosa $37,65 \%$, pentosan $27,93 \%$, lignin $22,09 \%$ serta $\mathrm{SiO}_{2} 3,01 \%$ yang dapat meningkatkan kuat tekan papan semen. Selain itu ampas tebu ini mudah didapat, murah, tidak membahayakan kesehatan dan dapat terdegradasi secara alami sehingga ampas tebu ini dapat diolah menjadi papan buatan seperti papan semen partikel (Husin., 2007).

Penambahan serbuk ampas tebu dalam penelitian ini bertujuan untuk meningkatkan sifat fisik dan mekanik papan semen partikel, mengetahui pengaruh penambahan serbuk ampas tebu tehadap sifat fisik dan mekanik papan semen partikel dan membandingkannya dengan standar mutu papan serta menentukan persentase optimum penambahan serbuk ampas tebu terhadap papan semen partikel yang dihasilkan. dengan persentase serbuk ampas tebu yang digunakan yaitu $0 \% ; 2,5 \% ; 5 \% ; 7,5 \%$ dan $10 \%$ terhadap volume cetakan. Hasil penelitian ini dibandingkan dengan Standar Nasional Indonesia (SNI) 03-2105-2006.

\section{METODE}

Penelitian ini dilaksanakan pada bulan Februari sampai Juli 2018. Pembuatan sampel dan pengujian sifat fisik papan semen partikel berupa (daya serap air, densitas, dan porositas) dilakukan di Laboratorium Fisika Material Jurusan Fisika Universitas Andalas. Pengujian sifat mekanik papan semen partikel berupa kuat tekan dan kuat lentur dilakukan di Laboratorium Mekanik Politeknik Negeri Padang. Peralatan yang digunakan sebagai berikut: neraca digital, Universal Testing Machine (UTM), ayakan ukuran 100 mesh, gelas ukur, sendok semen, mixer, ember, cawan porselin, kikir, ball mill, cetakan ukuran $5 \mathrm{~cm} \times 5 \mathrm{~cm} \times 1 \mathrm{~cm}$ dan cetakan ukuran $20 \mathrm{~cm} \times 5 \mathrm{~cm} \times 1 \mathrm{~cm}$. Bahan penelitian yang digunakan seperti semen Portland dari PT. Semen Padang, pasir, air, dan serbuk ampas tebu.

Ampas tebu terlebih dahulu direndam dengan mengunakan air panas selama 2 jam kemudian dikeringkan dibawah sinar matahari \pm 2 hari (sampai benar-benar kering). Ampas tebu yang telah kering dipotong-potong kemudian digiling dan diayak mengunakan ayakan 100 mesh. Pasir terlebih dahulu direndam selama 2 jam untuk menghilangkan zat lumpur yang terdapat pada pasir, kemudian pasir dikeringkan dibawah sinar matahari \pm 1 hari (sampai benarbenar kering). Pasir yang telah kering digiling dan diayak menggunakan ukuran 100 mesh. Pasta beton yang dibuat dengan rasio semen:pasir yaitu 1:2 dan faktor air semen (FAS) 0,4. Sampel dibuat 3 buah untuk masing-masing variasi persentase serbuk ampas tebu.

Pengujian sampel uji dilakukan setelah berumur 28 hari dengan pengujian sifat fisik yaitu uji daya serap air, densitas, dan porositas sedangkan pengujian sifat mekanik yaitu uji kuat tekan dan kuat lentur. Nilai sifat fisik dan mekanik yang diperoleh dalam penelitian ini dibandingkan dengan standar mutu SNI 03-2105-2006.

368 


\subsection{Pengujian Densitas}

Nilai densitas dilakukan dengan mengukur massa kering sampel dalam satuan gram dan mengukur panjang, lebar serta tebal sampel untuk mendapatkan volumenya dalam satuan $\mathrm{cm}^{3}$. Nilai densitas sampel uji dihitung menggunakan Persamaan 1.

$$
\rho=\frac{m_{k}}{V}
$$

dengan $\rho$ merupakan densitas $\left(\mathrm{g} / \mathrm{cm}^{3}\right), m_{k}$ merupakan massa kering sampel sebelum direndam dalam air ( gram). $V$ merupakan volume sampel uji $\left(\mathrm{cm}^{3}\right)$

\subsection{Pengujian Daya Serap Air}

Mula-mula sampel uji direndam pada suhu ruang selama 24 jam. Lalu sampel uji diangkat dan dikeringkan dengan kain hingga airnya tidak menetes lagi. Kemudian sampel uji ditimbang menggunakan neraca digital dan dicatat hasilnya sebagai $m_{b}$. setelah itu dilakukan perhitungan menggunakan Persamaan 2.

$$
\text { Daya Serap Air }=\frac{m_{b}-m_{k}}{m_{k}} \times 100 \%
$$

dengan $m_{k}$ merupakan massa kering (gram), $m_{b}$ merupakan massa basah (gram).

\subsection{Pengujian Porositas}

Pengujian porositas dilakukan pada sampel uji daya serap air. Perhitungan porositas dapat dilakukan denggan menggunakan Persamaan 3.

$$
\text { Porositas }=\frac{m_{b}-m_{k}}{V} \times \frac{1}{\rho_{a}} \times 100 \%
$$

dengan $m_{k}$ merupakan massa kering sampel (gram), $m_{b}$ merupakan massa sampel setelah direndan (gram), $V$ merupakan volume uji dengan satuan $\mathrm{cm}^{3}, \rho_{a}$ merupakan massa jenis air dengan nilai $1 \mathrm{~g} / \mathrm{cm}^{3}$.

\subsection{Pengujian Kuat Tekan}

Mula-mula sampel diukur panjang, lebar dan tebal dengan menggunakan jangka sorong dan hasil dicatat. Kemudian sampel uji diberi beban secara vertikal dan dicatat perubahan sampel akibat diberi beban maksimum secara vertikal hingga sampel uji retak. Nilai kuat tekan dapat dihitung menggunakan Persamaan 4

$$
f_{c}=\frac{P}{A}
$$

dengan $f_{c}$ merupakan kuat tekan $\left(\mathrm{kg} / \mathrm{cm}^{2}\right), \quad P$ merupakan beban maksimum $(\mathrm{kg})$ dan $A$ merupakan luas permukaan sampel $\left(\mathrm{cm}^{2}\right)$.

\subsection{Pengujian Kuat Lentur}

Mula-mula sampel diukur lebar dan tebalnya dengan jangka sorong dan dicatat hasil pengukuran. Kemudian dilakukan pengujian kuat lentur menggunakan mesin UTM dengan meletakkan sampel secara mendatar pada tumpuan. Sampel diberikan beban pada bagian pusat dan dicatat perubahan sampel akibat diberi beban secara vertikal hingga sampel uji patah. Nilai kuat lentur dapat dihitung menggunakan Persamaan 5.

$$
f_{r}=\frac{3 m_{p} S}{2 L T^{2}}
$$

dengan $f_{r}$ merupakan kuat lentur $\left(\mathrm{kg} / \mathrm{cm}^{2}\right), m_{p}$ merupakan beban maksimum $(\mathrm{kg}), S$ merupakan jarak tumpuan sampel terhadap beban (dalam penelitian ini jarak tumpuannya $15 \mathrm{~cm}$ ), $L$ 
merupakan lebar sampel uji (dalam penelitian ini $5 \mathrm{~cm}$ ) dan $T$ merupakan tebal sampel uji (dalam penelitian ini $1 \mathrm{~cm}$ ).

\section{HASIL DAN DISKUSI}

\subsection{Densitas}

Gambar 1 merupakan hasil pengujian densitas untuk papan semen partikel dengan variasi serbuk ampas tebu $0 \% ; 2,5 \% ; 5 \% ; 7,5 \%$; dan $10 \%$. Hasil penelitian untuk seluruh variasi serbuk ampas tebu telah memenuhi standar mutu SNI 03-2105-2006. Nilai densitas semakin menurun seiring bertambahnya persentse serbuk ampas tebu dengan nilai densitas secara berturut-turut $1,724 \mathrm{~g} / \mathrm{cm}^{3}, 1,719 \mathrm{~g} / \mathrm{cm}^{3}, 1,714 \mathrm{~g} / \mathrm{cm}^{3}, 1,711 \mathrm{~g} / \mathrm{cm}^{3}$ dan $1,696 \mathrm{~g} / \mathrm{cm}^{3}$. Hal ini dikarenakan adanya faktor butir sampel, pori dan komposisi bahan itu sendiri sehingga mengakibatkan penurunan densitas papan semen partikel. Densitas terendah pada persentase serbuk ampas tebu $10 \%$ yaitu $1,67 \mathrm{~g} / \mathrm{cm}^{3}$ dan densitas tertinggi pada persentase serbuk ampas tebu $0 \%$ sebesar $1,724 \mathrm{~g} / \mathrm{cm}^{3}$.

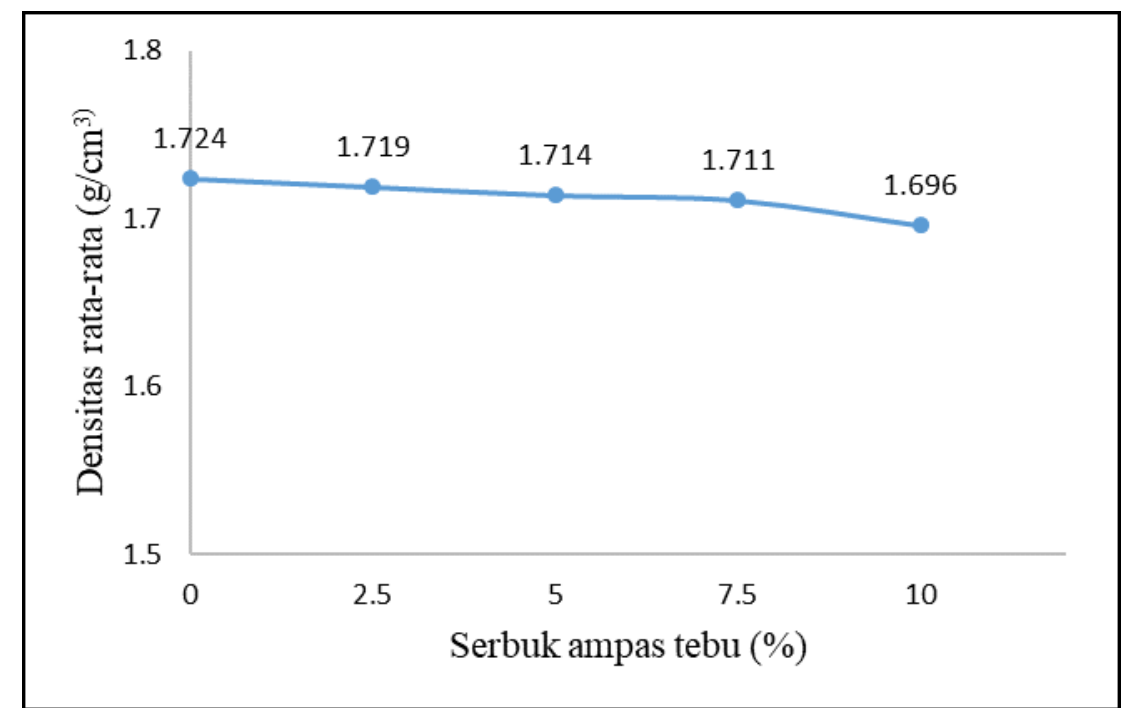

Gambar 1 Pengaruh persentase serbuk gondok terhadap densitas papan semen partikel.

\subsection{Uji Daya Serap Air}

Gambar 2 merupakan hasil pengujian daya serap air untuk papan semen partikel terhadap variasi serbuk ampas tebu dengan nilai daya serap air kurang dari $40 \%$. Nilai daya serap air rata - rata yang dihasilkan berkisar antara 10,54 sampai $12,77 \%$. Daya serap air terendah pada persentase serbuk ampas tebu $0 \%$ yaitu $10,54 \%$ dan daya serap air tertinggi pada persentase serbuk ampas tebu $10 \%$ sebesar $12,77 \%$. Kenaikan nilai daya serap air ini disebakan oleh sifat higroskopis ampas tebu yang mudah menyerap air. Heygreen dan Bowyer (1996) menyatakan bahwa tingginya nilai daya serap air disebabkan oleh kandungan higroskopis yang sangat mudah menyerap air. Berdasarkan SNI 03-2105-2006 tidak mensyaratkan nilai daya serap air, tetapi pada standar FAO 1996 menetapkan nilai daya serap air yaitu 6-40\%. 


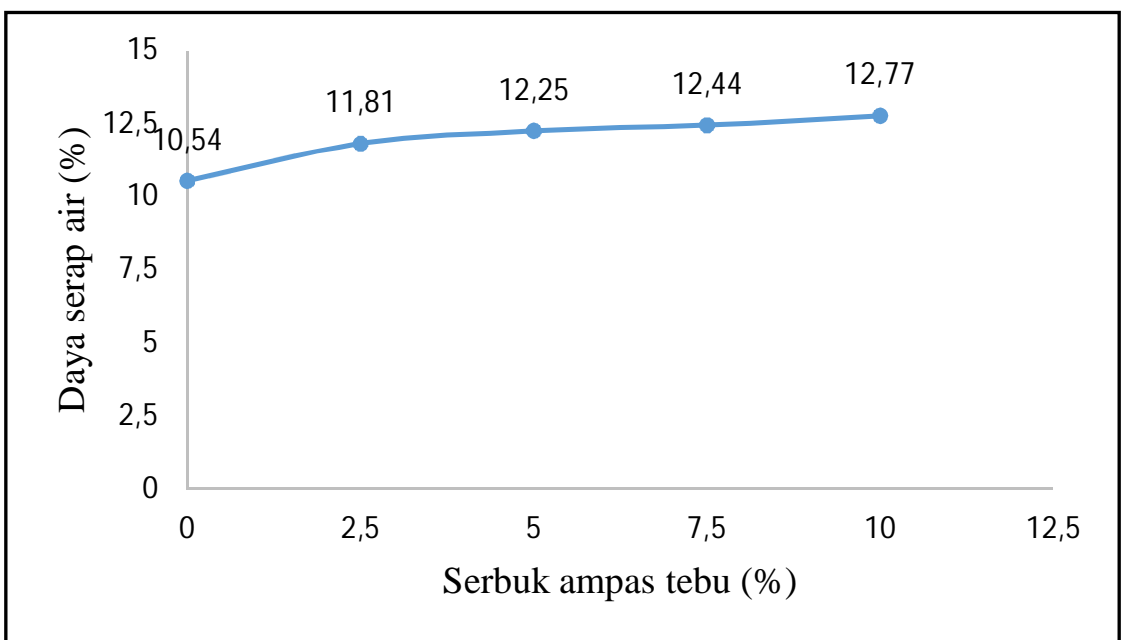

Gambar 2 Pengaruh persentase serbuk ampas tebu terhadap daya serap air papan semen partikel.

\subsection{Uji Porositas}

Gambar 3 menunjukkan kenaikan nilai porositas rata-rata seiring bertambahnya persentase serbuk ampas tebu. Papan semen partikel dengan serbuk ampas tebu memiliki nilai porositas rata-rata yang dihasilkan berkisar antara $18,16-21,67 \%$. Porositas terendah pada persentase serbuk ampas tebu $0 \%$ yaitu $18,16 \%$ dan porositas tertinggi pada persentase serbuk ampas tebu $10 \%$ sebesar $21,67 \%$. Nilai porositas meningkat seiring dengan penambahan serbuk ampas tebu hal ini diakibatkan karena penambahan ampas tebu menyebabkan banyaknya rongga udara atau void pada papan semen partikel. Semakin kecil nilai densitas maka daya serap air semakin tinggi. Dengan demikian dapat dikatakan nilai porositas berbaanding terbalik dengan nilai densitas.

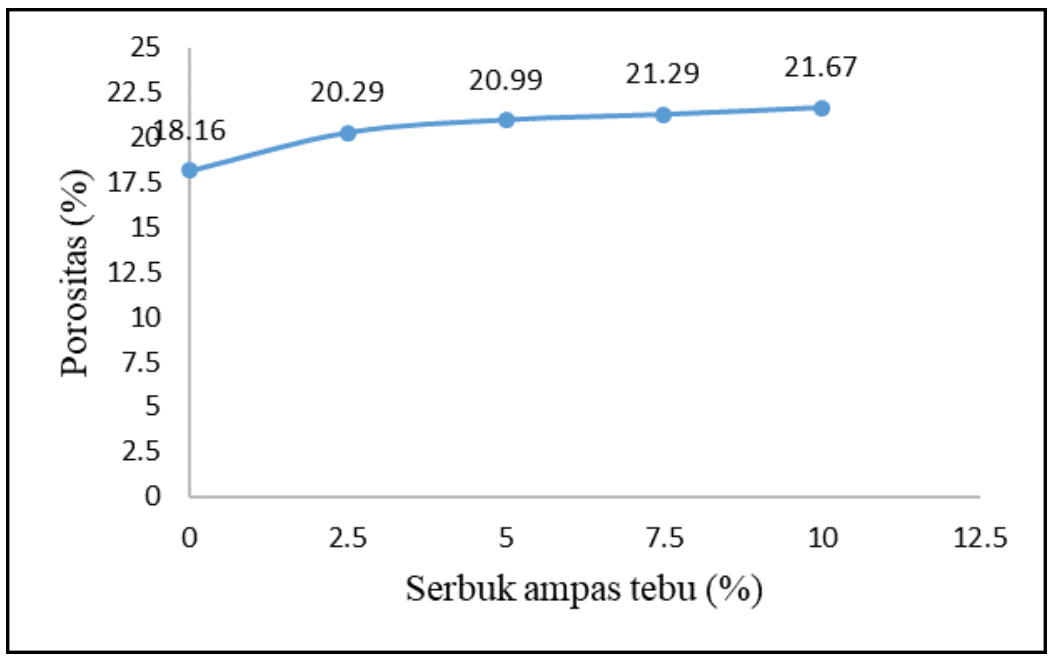

Gambar 3 Pengaruh serbuk ampas tebu terhadap porositas papan semen partikel.

\subsection{Uji Kuat Tekan}

Pengaruh penambahan serbuk ampas tebu terhadap nilai kuat tekan rata-rata papan semen partikel dapat dilihat pada Gambar 4. Nilai kuat tekan papan semen yang dihasilkan dengan penambahan serbuk ampas tebu berkisar antara $34,14-52,4 \mathrm{~kg} / \mathrm{cm}^{2}$. Nilai kuat tekan terendah yaitu $34,14 \mathrm{~kg} / \mathrm{cm}^{2}$ pada penambahan $10 \%$ ampas tebu ${ }^{3}$. Nilai kuat tekan tertinggi pada penambahan 5\% ampas tebu sebesar $52,4 \mathrm{~kg} / \mathrm{cm}^{2}$. Peningkatan kuat tekan papan semen partikel pada penambahan serbuk ampas tebu 5\% diduga karna adanya ikatan yang baik antara matriks (semen dan pasir) dan filler (ampas tebu) pada papan semen partikel sehinga menyebabkan nilai kuat tekan pada papan semen partikel bertambah. Penambahan serbuk ampas tebu yang sedang 
yaitu sebesar 5\% akan mudah bercampur dengan semen dan pasir sehingga mengakibatkan kuatnya ikatan semen dengan filler. Sebaliknya terlalu besar dan sedikit penambahan serbuk ampas tebu akan menyebabkan kekuatan papan semen rendah karna ikatan semen dengan filer tidak begitu kuat. Hasil pengujian nilai kuat tekan belum memenuhi standar mutu SNI 03-34492002 untuk struktural ringan yaitu dengan rentang nilai kuat tekan $68,9-172,4 \mathrm{~kg} / \mathrm{cm}^{2}$.

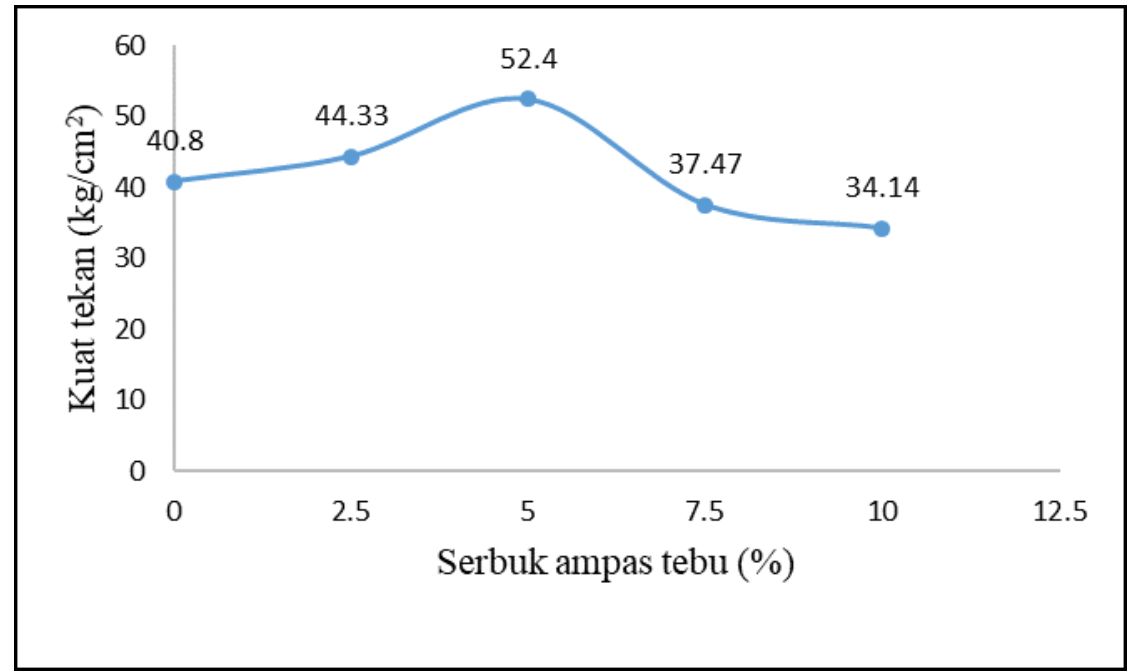

Gambar 4 Pengaruh persentase serbuk ampas tebu terhadap kuat tekan papan semen partikel.

\subsection{Uji Kuat Lentur}

Pengaruh persentase serbuk ampas tebu terhadap kuat lentur papan semen partikel lebih jelasnya dapat dilihat pada Gambar 5. Nilai kuat lentur yang dihasilkan pada penelitian ini berkisar antara $12-40,5 \mathrm{~kg} / \mathrm{cm}^{2}$. Nilai kuat lentur terendah pada penambahan $10 \%$ ampas tebu sebesar $12 \mathrm{~kg} / \mathrm{cm}^{2}$ dan nilai kuat lentur tertinggi pada penambahan $0 \%$ ampas tebu sebesar 40,4 $\mathrm{kg} / \mathrm{cm}^{2}$. Semakin besar penambahan serbuk ampas tebu maka nilai kuat lentur yang dihasilkan akan semakin kecil. Nilai kuat lentur yang dihasilkan sebanding dengan nilai densitas. Semakin tinggi kuat patah papan semen makan semakin tinggi juga densitas papan semenya. Penambahan ampas tebu yang menyebabkan semakin rendahnya nilai kuat lentur papan semen hal ini diakibatkan karena kandungan dari ampas tebu yang mengandung gabus yang tidak memiliki kekuatan serta kekutan serbuk ampas tebu dalam menahan beban yang kurang baik. Sehingga semakin banyak persentase serbuk ampas tebu yang digunakan menyebabkan menurunya nilai kuat lentur papan semen partikel. Pengujian kuat lentur yang dihasilkan belum memenuhi SNI 03-2105-2006 yang mensyaratkan nilai kuat lentur papan semen minimal 82 $\mathrm{kg} / \mathrm{cm}^{2}$.

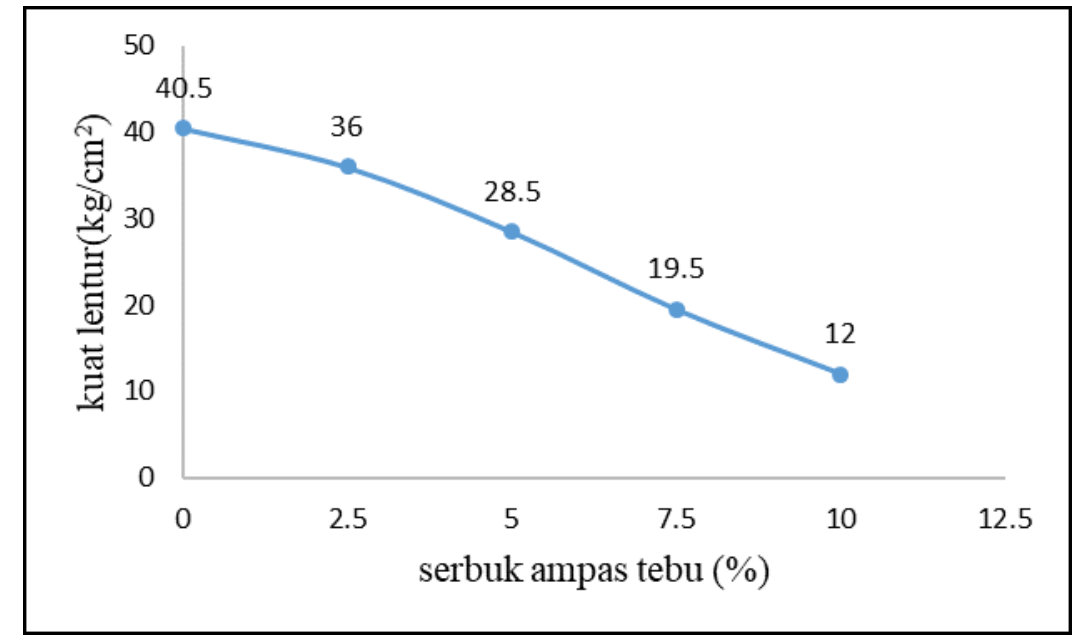

Gambar 5 Pengaruh persentase serbuk ampas tebu terhadap kuat lentur papan semen partikel. 


\section{KESIMPULAN}

Dari penelitian yang telah dilakukan dapat disimpulkan bahwa persentase serbuk ampas tebu digunakan sebagai bahan baku dalam pembuatan papan semen partikel dengan persentase serbuk $5 \%$ terhadap volume papan. Parameter ini ditentukan karena pada persentase serbuk ampas tebu $5 \%$ dihasilkan nilai kuat tekan papan semen partikel yang paling tinggi dan hampir mendekati standar mutu papan.

\section{DAFTAR PUSTAKA}

Haygreen, J.G., dan Bowyer, J.L., Pengantar Hasil Hutan dan Ilmu Kayu, Edisi ketiga, Gadjah Mada University, Yogyakarta, hal 528-529 (1996).

Husin, Analisis Serat Bagas, http://www.free.vlsm.org/, (2007) diakses 15 Februari 2018.

Iswanto, A.H., Papan Partikel dari Ampas Tebu, Skripsi, Departemen Kehutanan, Fakultas Pertanian Universitas Sumatera Utara, Medan (2009).

Nopriantina, N., Pengaruh Ketebalan Serat Pelepah Pisang Kepok (Musa Paradisiaca) Terhadap Sifat Mekanik Material Komposit Poliester-Serat Alam, Jurnal Fisika Unand, 2, hal 20-24 (2013,).

Pardede, D., Analisa Kajian Tegangan Beton dengan Campuran Serat Ampas Tebu, Universitas Sumatera Utara, Medan (2014).

Smallman, R.E. dan Bishop R.J., Matalurgi Fisik Modern dan Rekayasa Material, Edisi Keenam, Erlangga, Jakarta (2000).

Supriyadi, A., Rendaman Tebu, Kanisius, Yogyakarta (1992).

Sutigno, P., Kliwon, S., dan Karnasudirdja, S., Sifat Papan Semen Lima Jenis Kayu. Laporan No 96 Lembaga Penelitian Hasil Hutan, Bogor (1977).

[BSN] Badan Standardisasi Nasional, Tata Cara Rencana Pembuatan Campuran Beton Ringan Dengan Agregat Ringan, Jakarta, SNI 03 - 3449- 2002 (2002).

[FAO] Food and Agriculture Organization, Plywood and Other Wood Based,(1996).

Standar Nasional Indonesia, SNI Mutu Papan Partikel, SNI 03-2105-2006, Jakarta, Badan Standar Nasional (2006). 